\title{
Governance of built-heritage in a restrictive political system: the involvement of non-governmental stakeholders
}

\author{
Hung, Holvert
}

\author{
Department of Public Policy \\ City University of Hong Kong
}

Tat Chee Avenue, Kowloon Tong, Kowloon, Hong Kong SAR

Email address: hung.holvert@cityu.edu.hk 


\title{
GOVERNANCE OF BUILT-HERITAGE IN A RESTRICTIVE POLITICAL SYSTEM: THE INVOLVEMENT OF NON-GOVERNMENTAL STAKEHOLDERS
}

\begin{abstract}
Built-heritage conservation has increasingly become Hong Kong people's urgent concern since the years leading up to the territory's change of sovereignty from Great Britain to China, under political rules in which development takes priority over conservation. Built-heritage is a symbol of cultural identity and thus Hong Kong people's awareness of the importance of preserving them (Henderson, 2008). NGOs' sense of urgency in getting involved in built-heritage conservation also stems from operating within a political system which Scott (2010) describes as having a restrictive policy-making process, lacking in responsiveness to public demands and expectations. NGOs have three basic functions, namely, service provision, advocacy, and monitoring. Two case studies are used to illustrate these functions. The findings indicate that NGOs are most intensely involved in advocacy. NGOs involved in service provision have been selected through tightly-controlled processes. NGOs' monitoring activities were very limited. I argue that NGOs' role in built-heritage conservation is limited due to the restrictive political system. However, NGOs demonstrated insistent and resilient opposition to any top-down approach to decision-making is a sign that leads to the belief that despite of and because of the nature of the political system, NGOs' involvement in built-heritage is not only likely to intensify but also expand with government increasing the openness of the policy process to contain public pressure.
\end{abstract}

Keywords: NGOs, built-heritage conservation, service provision, advocacy, monitoring, civil society

\section{Introduction}

For the most part of the colonial era, cultural heritage was not a priority for the government and the Hong Kong people. For Britain, Hong Kong was to be transformed into a commercial port and a port of call for the British navy. For majority of its residents, Hong Kong was a place of refuge from the political and economic turmoil in the Mainland as well as an ideal place to make profit. (Yung and Chan, 2011) However, as the reunification of Hong Kong to the Motherland in 1997 approached, local residents' awareness of the importance of conserving their city's heritage sites increased (Henderson 2008). Hongkongers consider heritage structures as witness to their unique cultural identity (Yung and Chan, 2011; Lu 2009) which is different from that of the Mainland Chinese (Henderson, 2002). The dismantling of the Star Ferry Pier and Queen's Pier in Central in 2007 particularly marked an important period in the history of built-heritage conservation in Hong Kong. 
Conservationists' expressed strong and passionate opposition such as hunger strikes, sending a letter to the Secretary for Development written with their own blood, and chaining themselves to columns around the pier on the eve of the demolition day. (Henderson, 2008) These events and similar others prompted the Chief Executive to acknowledge Hong Kong people's passion for culture and promised to pay greater attention to heritage conservation (Tsang, 2007).

While the government recognized this change in Hong Kong people's attitude, development continued to take priority over heritage conservation due to various factors such as increasing demand for housing and office space, limited amount of developable land, huge constraints to land reclamation, and land premium being one of the major sources of government revenue. As Lung (2012: 132) puts it, "...heritage is not solely a cultural issue. When it comes to implementation, it is an issue of land economics.”

A more important factor is the restrictive political system in which the government tends to consider its policy views superior to those of the public (Scott, 2010). Other scholars on Hong Kong politics (Ma, 2007; Cheung, 2008) hold the same view as Scott (2010). However, some signs of a more open policy process have been seen (Cheung, 2011), particularly in the area of built-heritage conservation since its purview has been transferred to the Development Bureau in July 2007. At the same time, caution is needed about concluding that the changes are adequate in responding and taking into account stakeholders' views and interests.

This article examines the roles of NGOs in built-heritage conservation in Hong Kong, using two case studies involving heritage sites, namely, Central Police Station (CPS) and Police Married Quarters (PMQ). Data for analysis were collected from documentation and some interviews. The documentation examined include, among others, relevant papers, memoranda, and minutes of meetings or hearings of the Legislative Council, District Councils, Antiquities Advisory Board, Town Planning Board and Metro Planning Committee; NGOs’ annual reports; newspaper reports and articles. Fourteen semi-structured interviews were conducted with relevant NGOs and government officials, each lasting for more than an hour. Snowball sampling was used to identify possible informants for the subsequent interviews. Few studies have examined public involvement in built-heritage conservation (Li, 2014). Of these, only a few relate to Hong Kong (for example, Cheung, 2011; Yung and Chan, 2011; Cheng and Ma, 2009).

The following section provides a review of academic literature on the role of NGOs. This is followed by a brief description of the features of the Hong Kong political system, informed by Scott's (2010) thesis. The two case studies are then introduced, followed by their involvement in terms of their basic roles of service provision, advocacy, and monitoring. The last section analyzes the findings in relation to how NGOs' roles in built-heritage conservation in Hong Kong are influenced by the political system. 
Roles of NGOs: service provision, advocacy, and monitoring

Many definitions of NGO commonly stress NGO's not-for-profit and autonomous nature (Salamon, 1994; Clarke, 1998; Kim 2000). NGOs are an important type of civil society organization concerned with defending civil society from state encroachment (Cohen and Arato, 1992; Bernhard, 1993; Diamond, 1994). Civil society is a space between the public sphere (state) and private sphere (family), on the one hand, and from the market economy, on the other. While the state and civil society are separate spheres, they constitute one another and therefore their relationship is symbiotic and complementary (Chandhoke, 1995).

A review of the literature indicates three conventional functions of NGOs, namely, service provision, advocacy, and monitoring. These three functions are analytically distinct from each other. The focus in service provision is the creation of benefits for the people without actual changes in policy; the objective in advocacy is policy influence (Jenkins, 1987 in Powell, 1987); the aim of monitoring is to ensure the implementation of a policy or program according to regulation or decision. While in other places education or socialization and mobilization are treated as distinct functions of NGOs (Foley and Edwards, 1998), in this study these are considered as strategies in advocacy, because NGOs use them not as ends in themselves but as means to influence policy.

Service provision involves providing services directly to the public (Foley and Edwards, 1998) or filling in gaps in the service-delivery role of the government which is unable to provide an urgent service adequately to the needy members of a community (Salamon, 2002). The goods and services NGOs can provide are varied in scope. In the context of built-heritage conservation, NGOs provide goods and services by managing built-heritage conservation projects (Cheng, Li and Ma, 2014).

Advocacy, according to Jenkins (2006 in De Brelaz and Alvez, 2009: 153), "aims to influence the decisions of an institutional elite in favor of a collective interest." Citizens promote change, either in legislation or state policy, in order to address a problem or demand and to seek a solution, which they think is more beneficial to the public than the one proposed by the government (Diamond, 1994). In built-heritage conservation, NGOs attempt to influence government decisions regarding the conservation, after use, and design of conservation projects. NGOs' advocacy work involves different types of activity. NGOs form coalitions or alliances with other groups and individuals in order to put greater pressure on the state. NGOs pool in their resources together, whether personnel, information or funds, to achieve a goal collectively (Eilstrup-Sangiovanni and Bondaroff, 2014).

While monitoring is closely related to advocacy, the former is analytically distinct from the latter because the goal of the former is compliance. NGOs monitor government performance (Ghaus-Pasha, 2004) and the implementation of a policy 
(Hoang, 2013); check abuses of state power and violations of the law (Diamond, 1994); and, undertake activities to expand government accountability (Lane and Morrison, 2006). NGOs' watchdog activities contribute to good governance (Ghaus-Pasha, 2004). NGOs' monitoring activities involve various activities and cover various aspects of government work. In built-heritage conservation, NGOs monitor the implementation of heritage conservation policy in various ways such as how grading criteria are applied in the grading process of heritage sites and whether graded heritage sites receive due protection.

\section{Hong Kong's restrictive political system}

Hong Kong has a restrictive political system characterized by a policy process where "the government tended to ignore those views that did not correspond with its own" (Scott, 2010: 183). Hong Kong has yet to develop full democracy for the selection of the Chief Executive, and making the city's top policy makers appointed through the Political Appointment System accountable to a Chief Executive does little to ensure responsiveness to stakeholders' interests (Cheung, 2005). The Chief Executive, his appointed political advisors, and high ranking civil servants dominate the policy-making process, leaving little room for public participation in the policy process (Yung and Chan, 2011). Constitutionally the Legislative Council's oversight powers are weak vis-à-vis the executive (Ma, 2007). The functional constituency system in the legislature and the Election Committee institutionalizes corporatism fosters government-business collusion in decision-making (Cheung, 2008). The numerous advisory and statutory bodies are seen as no more than a co-optation tool for political patronage (Cheung and Wong, 2004), political window dressing (Hood, 1981), and pre-empting potential opposition to government policies (Miners, 2000). These advisory bodies lack independence and do not have a significant role in the policy process (Cheung, 2011). While advisory bodies incorporate societal elements, their advice is not binding (Holliday and Hui in Lam et al. 2007). Public consultations carried out by the government on policy issues are seen as tokenistic and are largely considered as a unidirectional form of engagement (CCSG, 2007; Lee and Thynne, 2011). 


\section{Two built-heritage conservation case studies}

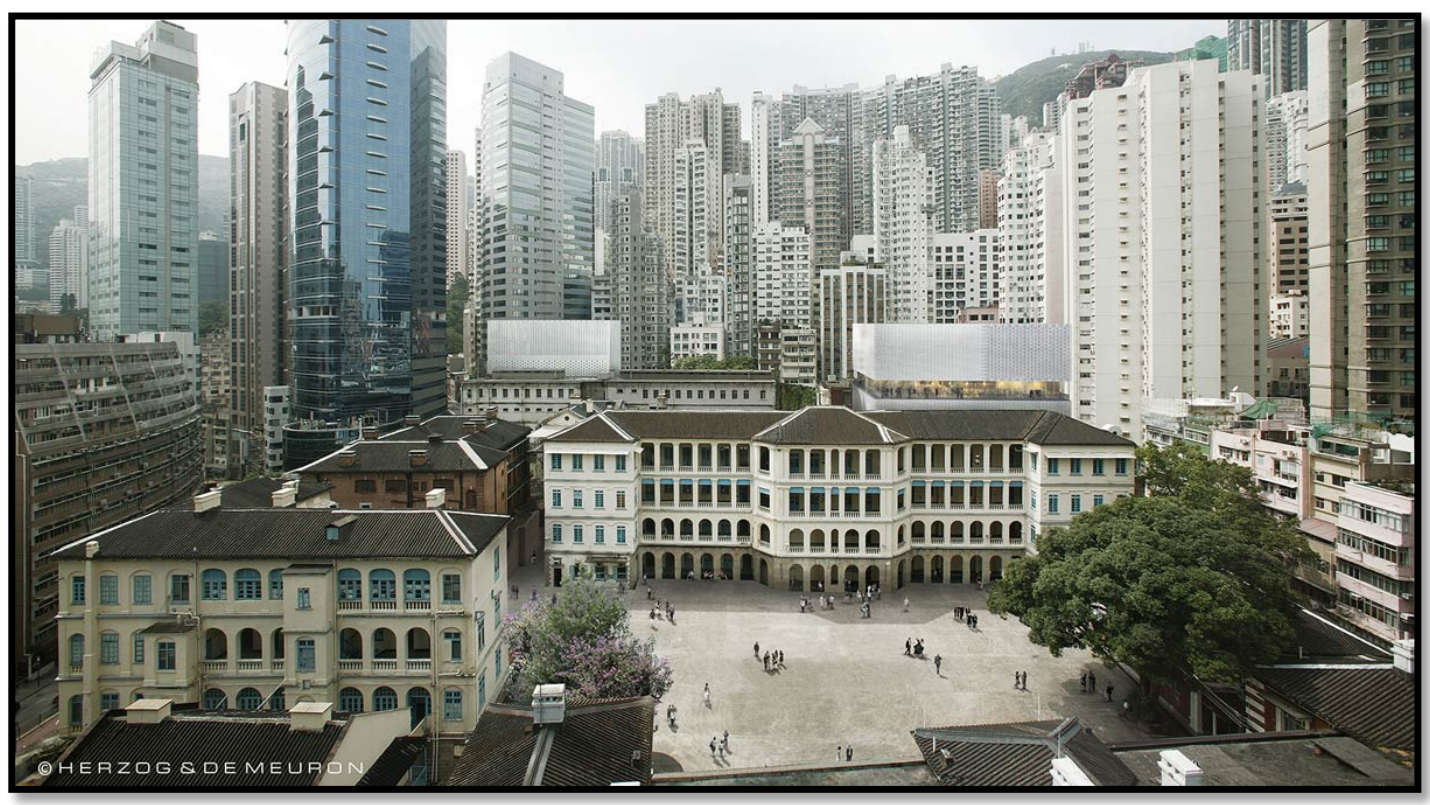

Figure 1: (Source: Commissioner for Heritage's Office of the Development Bureau)

The CPS compound (Figure 1), comprising three groups of buildings namely, the Central Police Station, the former Central Magistracy and Victoria Prison, represent law and order in Hong Kong. CPS was declared a monument on September 8, 1995. (AMO, 2004) In 2002, the government announced its plan to develop CPS into a heritage tourism project. In 2003, the Town Planning Board rezoned ${ }^{1}$ the site from "Government, Institution and Community" to "Other Uses," and arrangements were made to invite the private sector to submit development proposals for the site which could yield as much as 220,580 square feet of space for commercial development

\footnotetext{
${ }^{1}$ The Town Planning Board, a statutory board established with the enactment of the Town Planning Ordinance in 1939, is responsible for "making provision for the systematic preparation and approval of plans for the lay-out of areas of Hong Kong as well as for the types of building suitable for erection therein and for the preparation and approval of plans for areas within which permission is required for development” (TPO, 1939: 1). The Outline Zoning Plans prepared by the Town Planning Board indicate the land-use zonings of individual planning scheme areas. Some examples of land-use zonings relevant to this study are Residential (Group A); Government, Institution and Community; Open Space; Specified for Other Uses; Greenbelt; and, Creative Industries. Land-use zonings can be annotated to indicate planning intentions. Land-use rezoning requires a Section 12A application that goes through the plan-making process administered by the Town Planning Board, involving a statutory publication period to allow the public to submit comments and representations, in support or in opposition, to relevant applications, and a statutory hearing, to allow the applicants and those who submitted comments and representations to address Board officials directly.
} 
(Moir, 2004). The Advisory Committee on Revitalization of Historic Buildings was formed to assess proposals, comprising various officials from relevant bureaus and departments, and representatives from the Antiquities Advisory Board and Hong Kong Tourism Board as non-scoring members. The private development was eventually scrapped and the Hong Kong Jockey Club was chosen to revitalize the site as a heritage tourism attraction and a cultural landmark, providing cultural and arts facilities such as exhibition venues, theatre and cinema. CPS was rezoned to "Other Specified Uses" annotated "Historical Site Preserved for Cultural, Recreational, and Commercial Uses," and granted permission to Hong Kong Jockey Club to develop the site (TPB, 2011b). Revitalization works began in September 2012 and were completed in 2014. CPS is set to be opened to the public in 2015.

The former PMQ (Figure 2), comprising two quarters blocks and an ancillary Junior Police Call Clubhouse building, was built in 1951 for married rank and file police officers, including Chinese. The former Chief Executive, Mr. Tsang Yam-kuen (2005-2012), spent his childhood years in the PMQ where his father served as a police officer for the Royal Hong Kong Police Force. While it is only a Grade Three ${ }^{2}$ heritage building, it is historically significant as it sits on the remains of the former Central School (Figures 3 and 4), the first government school to provide Western education to the public, and the school's link to Dr. Sun Yat-Sen, founder of modern China.

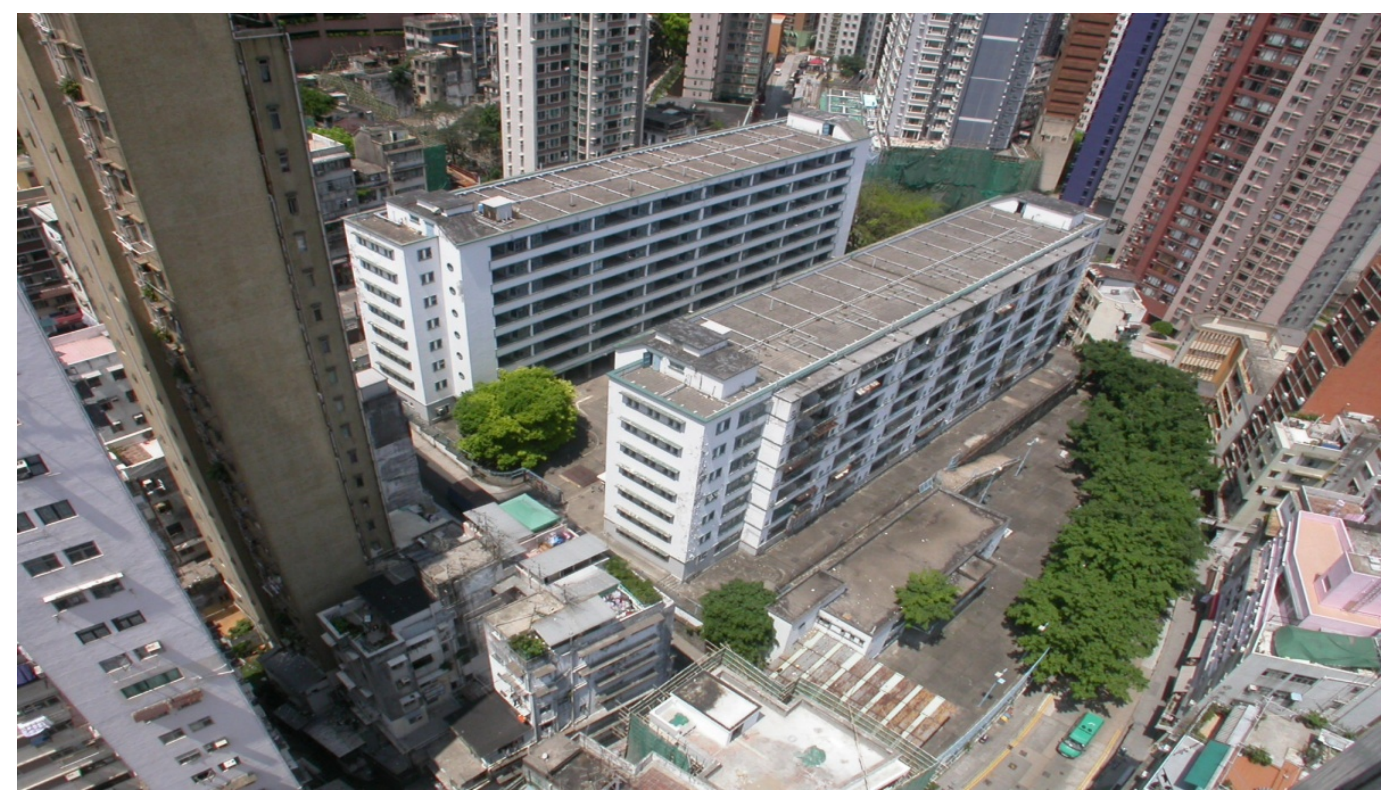

Figure 2 (Source: Commissioner for Heritage's Office of the Development Bureau)

\footnotetext{
${ }^{2}$ In Hong Kong, the existing heritage grading system has three grades, namely, Grade One, for buildings of outstanding merit; Grade Two, for buildings of special merit; and, Grade Three, for buildings of some merit. Graded buildings do not have any statutory protection. (DB, 2007)
} 
In 1998, PMQ was rezoned for residential development. In 2000, was included in the List of Sites for Sale. The site had a market value of 3.7 billion Hong Kong dollars and a potential of yielding 844,000 square feet of residential space. Eventually, the government decided to cancel the private tender and invite proposals to develop PMQ for creative industries and education, providing studios for rent, venues for design activities, and public open space. In January 2010, the PMQ site was rezoned from "Residential” to “Other Specified Uses” annotated "Heritage Site for Creative

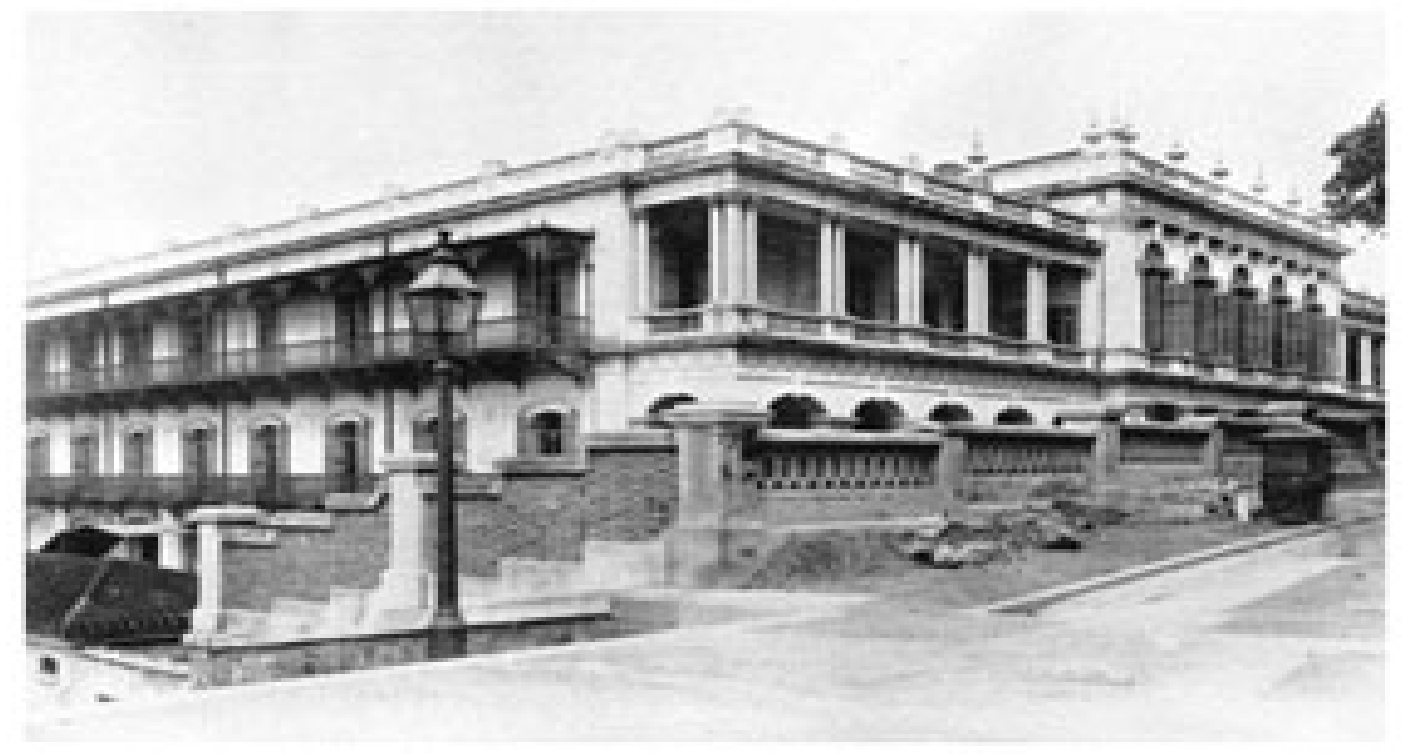

Figure 3 (Source: Commissioner for Heritage's Office of the Development Bureau) 


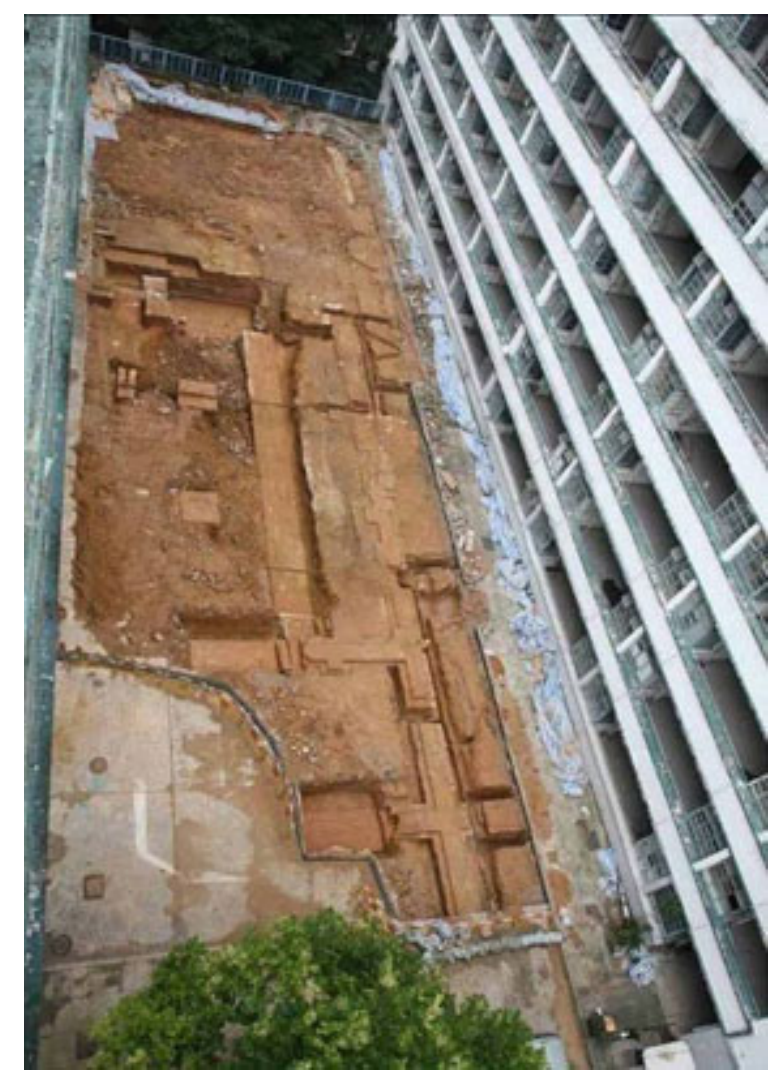

Figure 4: Excavated remains of Central School (Source: Commissioner for Heritage's Office of the Development Bureau)

Industries and Related Uses" (TPB, 2010a; TPB, 2010b). The assessment panel assessed four proposals, and selected the design submitted by the Three Musketeers Education and Culture Charitable Foundation Limited which provided a seed fund of 110 million Hong Kong dollars. Revitalization works began in January 2012, and was completed at the end of 2013. It was officially inaugurated in 2014.

\section{NGO involvement in built-heritage conservation}

\section{Service provision role}

In 2003, the government decided to earmark the CPS site for a heritage-related tourism project and scheduled a private tender for 2004. The successful bidder would be required to pay a land premium up front in return for a fifty-year lease. Robert Ho Yau-chung, Chairman of the Robert H.N. Ho Family Foundation, a philanthropic Foundation, became concerned about government plans for CPS, and was reported saying, "We felt that if past experience is any good example...the eventual development is going to be pretty disappointing” (Moir, 2004: EDT 12). The past 
experience he referred to was the "government's track record of in turning historical sites into restaurants or supermarkets” (Moir, 2004: EDT 12). Mr. Ho approached the government and had several meetings with top officials to discuss his proposal of converting CPS into a large arts academy funded by five hundred million in donations, provided the government offered the site on a private treaty grant basis, with little or no land premium. The arts complex would be run by a non-profit foundation or trust, which should be allowed to charge on a cost recovery basis with any surplus revenue ploughed back into development. The complex would include revenue-generating space such as cafes, display areas, galleries, and small studio theatres for artists. According to Mr. Ho, three or four established Hong Kong families have already pledged to give a total of one hundred million, and he was confident of being able to raise other four hundred million which would be used for the restoration of the CPS compound. However, the proposal was not approved and the Tourism Commission announced that the private tender would take place as scheduled. Thus, an attempt by an NGO to provide goods and services in built-heritage conservation failed.

\section{Advocacy role}

Conservationist NGOs were actively advocating for the preservation of CPS. Conservancy Association submitted a Section 12A application ${ }^{3}$ to the Town Planning Board in 2002 and organized a public workshop in 2003. In 2004, an alliance of several NGOs formed the CPS Heritage Taskforce and organized public participation activities to raise public awareness and to rally public support, advocating for a 'Heritage First' principle and a Citizen-Envisioned Participatory Assessment Model. They carried out a public survey and publicized the results in local newspapers. Representatives from various NGOs attended a Legislative Council panel meeting in 2004, demanding that the tendering exercise be cancelled and that monetary considerations should not take priority over preservation. (LC, 2004)

In November 2006, Conservancy Association and Heritage Hong Kong Foundation urged the Town Planning Board to introduce a Planning Brief ${ }^{4}$ to the Schedule of Notes $^{5}$ of CPS indicating a maximum building height restriction. The representation was not upheld, but several sympathetic comments from Board members were heard during the hearing. When Conservancy Association and Heritage Hong Kong Foundation found out that these supportive remarks had been toned down in the minutes, they launched a judicial review, accusing the government of manipulating the minutes. However, the judicial review was withdrawn when the government

\footnotetext{
${ }^{3}$ Cf. Footnote 1

${ }^{4}$ A planning brief sets out the planning parameters and development requirements for a specific area, for example, building height restrictions and plot ratio (PD, 2011).

${ }^{5}$ Each plan is accompanied by a Schedule of Notes which show for a particular zone the uses always permitted (Column One Uses) and uses that would require permission from the Town Planning Board (Column Two Uses) upon application (PD, 2005).
} 
cancelled the private tender and announced that the revitalization of CPS would be entrusted to the Hong Kong Jockey Club.

NGOs criticized the selection process from which they were excluded and the conceptual design proposed by Hong Kong Jockey Club. A series of public consultation exercises were held in 2007-2008 during which NGOs criticized the height of the proposed new structure and the demolition of some existing structures. Heritage Hong Kong Foundation organized their own exhibition proposing alternative designs and asked the public to give comments. In 2009, an alliance of thirteen NGOs urged the Town Planning Board to include a building height restriction in the Schedule of Notes. Majority of the public comments received supported the application (TPB, 2009). But the application was again not upheld. However, the height of the new structure was eventually reduced significantly (TPB 2010b).

Central and Western Concern Group took the lead in advocating for the preservation of PMQ, submitting several rezoning applications to the Town Planning Board in 2005, 2007 and 2008 (TPB, 2005; TPB, 2007; TPB, 2008). During the statutory publication periods of the planning process, they tried to raise public awareness by organizing exhibitions, information displays, and signature campaigns. They also sent letters to relevant government departments, providing supplementary information about the significance of the site. They urged the Town Planning Board to limit high-rise development and plot ratio in favor of public open spaces and minimizing negative impact on traffic flow and air quality. Unfortunately, none of these applications were upheld by the Town Planning Board. However, the government eventually decided to remove the site from the Land Sale List and to revitalize PMQ as a hub for creative industries and education. The government also scrapped the proposed two high-rise residential towers and the plan to demolish the Junior Police Call. While these were positive developments, the selection of project operator lacked adequate public participation which Central and Western Concern Group criticized (TPB, 2011a).

\section{Monitoring role}

Central and Western Concern Group acted as a watchdog in the CPS case, particularly when they criticized the government for what they considered as a procedural anomaly in the approval of the Environmental Impact Assessment and the issuance of the environmental permit by the Environmental Protection Department even before the archaeological investigation was conducted. Albert Lai, one of the Directors of Conservancy Association, questioned the practice, criticizing it as a compliant report and accusing the government of disregarding the checks-and-balance system $\mathbf{~} \mathbf{N g}$, 2011).

In 2007, Central and Western Concern Group was granted permission to be present during the archaeological investigation on the PMQ site. The Group monitored the 
investigation and informed the public through the media of its progress. The Central School remnants found during the archaeological investigation were substantial, and initially, as the Group noted, there was reluctance on the part of the government to be transparent and clear about the findings during their meeting with the Central and Western District Council. (Batten and Law, 2008: 4)

NGOs tried to make the officials of Antiquities Advisory Board and Town Planning Board more accountable to the public. They 'appealed to the conscience' of officials, urging them to decide based on public interest and not to toe the government's line. In a 2005 Town Planning Board hearing on PMQ, NGOs addressed the following words to officials: "the Board should take a proactive approach for preservation of heritage, rather than pending the Government's review of the heritage preservation policy" (TPB, 2005: 29). In 2006, NGOs told officials “...take on a custodian/stewardship role of the site... and take up the role of arbiter in determining the appropriate uses or development of the CPS compound in future” (TPB, 2006: 19-20). Heritage Hong Kong Foundation criticized the Town Planning Board officials for not performing their duty of setting the key planning parameters, including BHR, to guide the project planning (TPB, 2009: 13-14) An informant remarked, "We keep on telling the Board to do what they are supposed to do. They tend to follow what the government is putting up.” (interview 2012)

\section{Findings}

Taking two controversial built-heritage conservation cases, this article examines the role of NGOs in policy-making in Hong Kong in terms of the basic functions of service provision, advocacy, and monitoring. The findings show that NGOs in built-heritage conservation in Hong Kong are most active in political advocacy, with limited activity in service provision and monitoring. NGOs' involvement in service provision is hampered by two possible constraints: internal and external. The main internal constraint is the lack of economic resources to provide goods and services in built-heritage conservation which are normally very costly. NGOs, whether new and small such as Central and Western Concern Group or well-established such as Conservancy Association, may not have the financial capacity to carry out such function. But even if NGOs have the economic resources, as in the case of a philanthropic foundation run by Robert Ho Yau-chung, who could have easily raised sufficient funds from his network of rich families to operate the CPS project, external forces such as the political context may restrict them from participating in service provision.

For example, the lack of clear and consistent criteria for the selection of operator, observed in two of the case studies, indicates the kind of political context in which Hong Kong NGOs operate. In the selection of the Three Musketeers to operate the PMQ project, track record seems to be not as crucial as economic capacity. In the CPS 
case, the government did not entrust the project to a philanthropic foundation even though it had proven to have the financial capacity. While the Hong Kong Jockey Club and the Musketeers Foundation are also NGOs, their selection however was done within an arrangement in which a continued control over the processes and the outcomes can be maintained by the government. HKJC was selected, after closed door talks between two parties, without any tendering process. The Musketeers Foundation was selected by the Advisory Committee on the Revitalization of Historic Buildings, comprising official members who are former government officials and non-official members.

Furthermore, NGOs' monitoring activities were rather episodic and were absent in the implementation stage of the project. Except for the monitoring of the archaeological investigation of the PMQ site by Central and Western Concern Group, NGOs' monitoring function basically consisted of pointing out and criticizing officials for anomalies in administrative procedures or for discrepancies between actual and perceived functions of advisory bodies. NGOs' monitoring activities were observed only during the planning stages, particularly during the statutory publication period. Once decisions have been finalized, they were difficult to change, and NGOs may not have the motivation to monitor the implementation of a decision which did not in the first place satisfy their demands.

Political advocacy is the function which was most actively performed by NGOs. They used a variety of means and strategies to express their views and to attempt to influence decisions. The means they used ranged from sending letters or proposals to government departments or agencies to participating government-initiated public forums, workshops, focus groups, open days, and exhibitions to participating in the plan making process of the Town Planning Board which included submitting applications, attending hearings, and sending comments during statutory publication periods to attending Legislative Council panel meeting to launching judicial reviews. NGOs also organized their own signature campaigns, exhibitions, surveys, and public forums. In addition, they used the media such as radio talk programs and newspapers to express their views, and they organized protest actions in their attempt to put more pressure on the government and to influence decisions.

The findings indicate that the methods and strategies used by NGOs to engage the government were impressive both in numbers and diversity. It can be said that the NGOs used a multi-channel approach, exhausting the methods available within the system, which required not an insignificant amount of resources. Applications to the Town Planning Board require technical information and understanding of planning which NGOs may not possess. But they were creative in overcoming their limitations, making alliances with other NGOs, tapping technical knowledge and skills within their networks, and using the media to disseminate information which lowers down the cost of trying to influence government decisions. NGOs have shown that they were prepared to take whatever action possible to prevent the government from making decisions without sufficiently engaging and being responsive to public views. 
This included even using legal means which, according to Cheung and Wong (2006), Hongkongers have increasingly used to challenge government decisions. Heritage Hong Kong Foundation has experienced government's wariness about such legal challenges. The Foundation and other NGOs would have no doubt thought of judicial reviews as a strategy to put pressure on the government to listen to their views.

The policy process involved in the case studies was more open. Some restructuring of government departments, reallocation of responsibilities, new approaches in engaging the public and procedural reforms contributed to the enhancement of inclusiveness and transparency of participation processes. Some reforms to the Town Planning Board procedures in 2005 enhanced transparency, for example, the public was given access to hearing minutes. When Carrie Lam Cheng Yuet-ngor became the Secretary for Development Bureau (2007-2012), she promoted more public participation in policy development, confirmed, for example, by the number and different types of engagement methods used in the area of built-heritage conservation. These are signs of some improvements from the conventional approach taken by the Hong Kong government to public consultation.

\section{Discussion}

The above phenomenon with regard to NGO's role in policy development is both a consequence of and a reaction to the restrictive political system. Given the political context, NGOs' role in the policy process in terms of service provision and monitoring is limited, and has mainly focused on political advocacy. Another way of understanding this phenomenon, especially the focus on political advocacy, is that NGOs have experienced that their advocacy work has made an impact, although limited but not necessarily insignificant, on final decisions, and have therefore used this as a strategy to compensate for limited role allowed by the system in service provision and monitoring.

Furthermore, NGOs' and stakeholders are not satisfied with these changes which have emphasized administrative more than statutory changes. Relevant advisory bodies continue to lack independence and the government-initiated participation methods, though more inclusive still lack responsiveness to public views. NGOs' limited involvement in built-heritage conservation in terms of their basic functions of service provision and monitoring also reflect a lack of consistency in government's commitment to engage the public which corroborates Scott's (2010: 304) observation that "the government's willingness to engage with civic groups is not a standard practice; it engages on some issues but not on others." The changes to the original plans and design for the relevant built-heritage sites, which were not insignificant, suggest that NGOs' involvement had had an impact on the decision-making process. However, what appears as government responsiveness may be only a tokenistic reaction to diffuse increasing public pressure instead of a genuine intent to share 
power. The former has been a typical tactic to maintain legitimacy within a situation of a lack of democratic governance (Ma, 2007; CCSG, 2007; Scott, 2010).

Based on the study's findings, it is important to note that built-heritage conservation is not just about the politics of identity but also about the politics of space. Adaptive reuse of heritage buildings also contributes to the reduction of greenhouse gases as it extends the life of buildings and avoids demolition wastes (Yung and Chan, 2012). NGOs consider built-heritage conservation as a means to provide Hong Kong people good living environment consisting of adequate public open space, smooth traffic flow, and good air quality.

Participation has the capacity to enhance the legitimacy of decisions and to build trust in government. NGO involvement in built-heritage conservation policy-making in Hong Kong can be seen as part of a global phenomenon. Citizens nowadays are more willing to accept, support and trust decisions made with their involvement rather than by the government or state-commissioned experts alone doing it on their behalf (OECD, 2005). Abundant literature on public participation also provide an indication of the level of involvement of civil society in various policy areas in terms of advocacy, service provision, and monitoring (for example, Zhan and Tang, 2013; Ahsan et al. 2012; Lakin, 2011; Pawelke, 2010; Obot, 2004; Rakodi, 1989). Engaging citizens in policy-making can result in greater trust in governments (OECD, 2001) which is essential not only for building effective working relationships (Tsang et al. 2009), but also "for the legitimacy of governance in policy development" (OECD, 2005: 86), the latter being particularly important in a political system lacking in democratic legitimacy (Scott, 2010). Additionally, trust reduces transaction costs of political bargaining (Tsang et al. 2009) and of policy implementation (Mandarano, 2009). Models of participatory processes such as collaborative planning lead to the formation of trust, which in turn fosters cooperative attitudes, necessary to achieving positive and successful outcomes (Mandarano, 2009).

Much of the extent to which NGOs can influence decisions depends on their creativity in enacting their participation. A research study that examines NGOs' strategies and the degree to which these can impact on the policy process can provide insights into the workings of public participation in Hong Kong and other places under quasi-democratic systems. Another research direction is to empirically establish the relationship between trust building and transaction cost (Coase, 1960) reduction in the process of political instead of market coordination. The study could hopefully provide governments interested in reducing transaction costs the impetus to foster trust formation by promoting participatory policy-making processes.

\section{Conclusion}

Although currently NGOs' role in built-heritage conservation is mainly limited to 
advocacy, there are signs that not only will they increase and diversify their advocacy work but also continue to try to expand their involvement in service provision and monitoring despite and because of the restrictive political system. One of the signs stems from the fact that Hong Kong has a vibrant and active civil society (Ma, 2007; Cheung, 2008). This article stresses an important feature of NGOs, inherent in them as civil society organizations, which is to defend civil society from state encroachment. According to Burns (2004: 36), there has been clear evidence that "Hong Kong people are now more demanding, better organized, better resourced and better able to articulate their interests.” The study shows that they used various means and strategies to defend civil society, opposing a top-down approach to decision-making, which has often characterized Hong Kong policy process (Scott, 2010), and public consultation exercises, which are characterized by tokenism rather than responsiveness (CCSG, 2007). With a policy-making process captured by the state which is, in turn, captured by business through an institutionalized corporatism built into the system (Cheung, 2008), NGOs and the community continue to harbor a deep-seated suspicion of government priorities when deciding between conservation and development which will lead NGOs to try to expand their role in built-heritage conservation.

The institutionalization of formal channels of participation is a good first step on the road towards enhancing the role of NGOs in built-heritage conservation particularly in service provision and monitoring. If taking into account stakeholders' interests is important for better planning and management of military heritage (Lai and Ho, 2003), this not only holds true but also even more urgent in the case of built-heritage where there are more values at stake. Concretely, there is a need for re-visiting the review exercise on the role and functions of the advisory and statutory bodies conducted by the Home Affairs Bureau in 2003 which although have dealt with important matters have skirted the more basic issue of the ways in which these bodies can enhance public engagement (Cheung, 2011). A second phase of the review exercise is necessary this time to address the core matters of openness, effectiveness, representativeness, and independence (Scott, 2006); work, power, and responsibility arrangements (Thynne, 2006).

In addition, there is a need for setting up a public engagement mechanism operating under a framework that provides substantial opportunities for stakeholders and officials to work together in designing the conservation and development parameters for the revitalization of a specific heritage site; in setting out the criteria for the selection of project design and project operator; and so on. This contributes to improving governance (OECD, 2005) and the work of policy makers whose task it is to "monitor the needs and aspirations of the community and having regard to the findings, to undertake timely review and to generate proposals” (CAB, 2002), to make decisions that are more aligned with public demands and expectations. The separation between the state and civil society does not presuppose disconnection. The state and civil society constitutes and informs one another (Chandhoke, 1995). While it is important to maintain their separation to protect civil society's autonomy, their 
connection is no less important which reflects their complementary roles and fosters effective policy-making.

\section{References}

1939. Town Planning Ordinance. Hong Kong: Hong Kong Legal Information Institute.

Ahsan, A., Alamgir, M., Imteaz, M., Daud, N. N. N. \& Islam, R. 2012. Role of NGOs and CBOs in Waste Management. Iranian Journal of Public Health, 41, 27-38.

Antiquities and Monuments Office. 2004. Introduction to the Central Police Station [Online]. Available: http://www.amo.gov.hk/ [Accessed January 25 2013].

Batten, J. \& Law, K. 2008. Comments by Central and Western Concern Group to the Administration's submission to the Panel on Home Affairs Sub-Committee on Heritage Conservation.

Bernhard, M. 1993. Civil society and democratic transition in East Central Europe. Political Science Quarterly, 108, 307-326.

Burns, J. P. 2004. Government capacity and the Hong Kong civil service, Hong Kong, Oxford University Press.

Centre for Civil Society and Governance 2007. From consultation to civic engagement: the road to better policy-making and governance. Hong Kong: Bauhinia Foundation Research Centre.

Chandhoke, N. 1995. State and civil society: Explorations in political theory, London Sage Publications Ltd.

Cheng, E. \& Ma, S. Y. 2009. Heritage Conservation through Private Donation: The Case of Dragon Garden in Hong Kong. International Journal of Heritage Studies, 15, 511-528.

Cheng, E. W., Li, A. H. F. \& Ma, S. Y. 2014. Resistance, Engagement, and Heritage Conservation by Voluntary Sector: The Case of Penang in Malaysia*. Modern Asian Studies, 48, 617-644.

Cheung, A. B. L. 2008. The story of two administrative states: state capacity in Hong Kong and Singapore. The Pacific Review, 21, 121-145.

Cheung, A. B. L. \& Wong, M. W. L. 2006. Judicial review and policy making in Hong Kong: changing interface between the legal and the political. The Asia Pacific Journal of Public Administration, 28, 117-141.

Cheung, A. B. L. \& Wong, P. C. W. 2004. Who advised the Hong Kong government?: the politics of absorption before and after 1997. Asian Survey, 44, 874-894.

Cheung, C. Y. 2005. The principal officials accountability system: not taking responsible government seriously? In: Cheng, J. Y. S. (ed.) The July 1 protest rally: interpreting a historic event. Hong Kong: City University of Hong Kong Press.

Cheung, E. W. \& Ma, S. Y. 2009. Heritage conservation through private donation: the case of dragon garden in Hong Kong. International Journal of Studies, 15, 
511-528.

Cheung, P. 2011. Civic engagement in the policy process in Hong Kong: change and continuity. Public Administration and Development, 31, 113-121.

Clarke, G. 1998. Non-governmental organizations (NGOs) and politics in the developing world. Political Studies, XLVI.

Coase, R. 1960. The Problem of Social Cost. The Journal of Law and Economics, 3, $1-44$.

Cohen, J. L. \& Arato, A. 1992. Civil society and political theory, Cambridge, Massachusetts, Massachusetts Institute of Technology Press.

Constitutional Affairs Bureau 2002. Accountability System for Principal Officials.

De Brelaz, G. \& Alves, M. A. 2009. Civil society organizations and advocacy: A comparative study between Brazil and the United States. Comparative Social Research, 26.

Development Bureau 2007. Heritage Conservation Policy.

Diamond, L. J. 1994. Toward Democratic Consolidation. Journal of Democracy, 5, 4-17.

Eilstrup - Sangiovanni, M. \& Bondaroff, T. N. P. 2014. From Advocacy to Confrontation: Direct Enforcement by Environmental NGO s. International Studies Quarterly, 58, 348-361.

Foley, M. W. \& Edwards, B. 1998. Beyond Tocqueville: Civil society and social capital in comparative perspective: Editors' introduction. American Behavioral Scientist, 42, 5-20.

Ghaus-Pasha, A. 2004. Role of civil society organizations in governance. 6th Global Forum on Reinventing Government: Towards Participatory and Transparent Governance. Seoul, Republic of Korea.

Henderson, J. C. 2002. Heritage attraction and tourism development in Asia: a comparative study of Hong Kong and Singapore. International Journal of Tourism Research, 4, 337-344.

Henderson, J. C. 2008. Conserving Hong Kong's Heritage: The Case of Queen's Pier. International Journal of Heritage Studies, 14, 540-554.

Hoang, T. A. 2013. Civil society organisations' roles in health development in Vietnam: HIV as a case study. Global Public Health, 8, S92-S103.

Holliday, I. \& Hui, G. K. H. 2007. Local, advisory and statutory bodies. In: Lam, W. M., Lui, P. L. T., Wong, W. \& Holliday, I. (eds.) Contemporary Hong Kong politics: governance in the post-1997 era. Hong Kong: Hong Kong University Press.

Hood, C. 1981. Axeperson, spare that QUANGO... In: Hood, C. \& Wright, M. (eds.) Big government in hard times. Oxford: Martin Robertson.

Hood, C. \& Wright, M. (eds.) 1981. Big government in hard times, Oxford: Martin Robertson.

Jenkins, J. C. 1987. Nonprofit organizations and policy advocacy. In: Powell, W. W. (ed.) The nonprofit sector: A research handbook. New Haven: Yale University Press.

Kim, H. R. 2000. The state and civil society in transition: the role of 
non-governmental organisations in South Korea. The Pacific Review, 13, 595-613.

Lai, L. W. C. \& Ho, D. C. W. 2003. Facilities management and planning for heritage sites: lessons learnt from a pilot study on disused military sites. Facilities, 21, 80-88.

Lakin, J. 2011. Jobs for all? A civil society guide for understanding and monitoring industrial budget policy [Online]. International Budget Partnership. Available: http://internationalbudget.org/civil-society-organizations/

[Accessed September 24 2014].

Lam, W. M., Lui, P. L. T., Wong, W. \& Holliday, I. (eds.) 2007. Contemporary Hong Kong politics: governance in the post-1997 era, Hong Kong: Hong Kong University Press.

Lane, M. B. \& Morrison, T. H. 2006. Public interest or private agenda? A meditation on the role of NGOs in environmental policy and management in Australia. Journal of Rural Studies, 22, 232-242.

Lee, E. \& Thynne, I. 2011. Symposium introduction: dynamics of governance and civic engagement. Public Administration and Development, 31.

Legislative Council 2004. Minutes of meeting of the Panel of Home Affairs, 09.11.2004.

Li, F. 2014. International influence and local response: understanding community involvement in urban heritage conservation in China. International Journal of Heritage Studies, 20, 651-662.

Lu, T. L. D. 2009. Heritage conservation in post-colonial Hong Kong. International Journal of Heritage Studies, 15, 258-272.

Lung, D. 2012. Built heritage in transition: a critique of Hong Kong's conservation movement and the Antiquities and Monuments Ordinance. Hong Kong Law Journal, 42, 121-141.

Ma, N. 2007. Political development in Hong Kong: state, political society, and civil society, Hong Kong, Hong Kong University Press.

Mandarano, L. A. 2009. Social Network Analysis of Social Capital in Collaborative Planning. Society \& Natural Resources, 22, 245-260.

Miners, N. 2000. The government and politics of Hong Kong, New York, Oxford University Press.

Moir, J. 2004. A question of love or money. South China Morning Post, August 9, 2004.

Ng, J. 2011. Green plan on police station not discussed. South China Morning Post, April 29, 2011.

Obot, I. S. 2004. Responding to substance use problems in Nigeria: The role of civil society organizations. Substance Use and Misuse, 39, 1287-1299.

Organization for Economic Cooperation and Development 2001. Engaging citizens in policy-making: information, consultation and public participation.

Organization for Economic Cooperation and Development 2005. Evaluating Public Participation in Policy Making, Paris, OECD.

Pawelke, A. 2010. Anti-corruption in Slovakia The Role of Civil Society. Romanian 
Journal of Political Science, 10, 96-117.

Planning Department. 2005. Frequently Asked Questions [Online]. Available: http://www.pland.gov.hk/ [Accessed October 11 2012].

Planning Department 2011. Hong Kong Planning Standards and Guidelines.

Powell, W. W. (ed.) 1987. The nonprofit sector: A research handbook, New Haven: Yale University Press.

Rakodi, C. 1989. After the project has ended - The role of a non-governmental organization in improving conditions of the urban-poor in Lusaka. Community Development Journal, 25, 9-20.

Salamon, L. M. 1994. The rise of the nonprofit sector. Foreign Affairs, 73.

Salamon, L. M. 2002a. The resilient sector: The state of non-profit America. In: Salamon, L. M. (ed.) The state of non-profit America. Washington, D.C.: Brookings Institution Press.

Salamon, L. M. (ed.) 2002b. The state of non-profit America, Washington, D.C.: Brookings Institution Press.

Scott, I. 2006. The government and statutory bodies in Hong Kong: centralization and autonomy, S.1., Springer Science + Business Media.

Scott, I. 2010. The public sector of Hong Kong, Hong Kong, Hong Kong University Press.

Town Planning Board 2005. Minutes of 316th meeting of the Metro Planning Committee, 25.11.2005.

Town Planning Board 2006. Minutes of 865th meeting of the Town Planning Board, 25.08.2006.

Town Planning Board 2007. Minutes of 343rd meeting of the Metro Planning Committee, 2.2.2007.

Town Planning Board 2008. Minutes of 385th meeting of the Metro Planning Committee, 21.11.2008.

Town Planning Board 2009. Minutes of 408th meeting of the Metro Planning Committee, 20.11.2009.

Town Planning Board 2010a. Minutes of 411th meeting of the Metro Planning Committee, 15.1.2010.

Town Planning Board 2010b. Minutes of 417th meeting of the Metro Planning Committee, 23.04.2010.

Town Planning Board 2011a. Minutes of 440th meeting of the Metro Planning Committee, 15.4.2011.

Town Planning Board 2011b. Minutes of 441st meeting of the Metro Planning Committee, 06.05.2011.

Tsang, S., Burnett, M., Hills, P. \& Welford, R. 2009. Trust, public participation and environmental governance in Hong Kong. Environmental Policy and Governance, 19, 99-114.

Tsang, Y. K. 2007. Chief Executive's Policy Address 2007-2008.

Thynne, I. 2006. Statutory bodies as instruments of government in Hong Kong: review beginnings and analytical challenge ahead. Public Administration and Development, 26, 45-53. 
Yung, E. H. K. \& Chan, E. H. W. 2011. Problem issues of public participation in built-heritage conservation: two controversial cases in Hong Kong. Habitat International, 35, 457-466.

Yung, E. H. K. \& Chan, E. H. W. 2012. Implementation challenges to the adaptive reuse of heritage buildings: Towards the goals of sustainable, low carbon cities. Habitat International, 36, 352-361.

Zhan, X. Y. \& Tang, S. Y. 2013. Political opportunities, resource constraints and policy advocacy of environmental NGOs in China. Public Administration, 91, 381-399. 